\title{
Research on the Academia da Cidade and Academia da Saúde Programs: scoping review
}

Pesquisas sobre os Programas Academia da Cidade e Academia da Saúde: revisão de escopo

\section{AUTHOR'S \\ Paulo Henrique Guerra ${ }^{1,2}$ (D) \\ Douglas Roque Andrade 2,3 (iD \\ Ciro Romelio Rodriguez-Añez ${ }^{4,5}$ (D) \\ Daniela Lopes dos Santos ${ }^{6}$ (D) \\ Edina Maria de $\mathrm{Camargo}^{7}$ (iD \\ Rogério César Fermino 4,5 (D) \\ Maria Cecília Marinho Tenório ${ }^{8,9}$ (D) \\ 1 Universidade Federal da Fronteira Sul, Chapecó, Santa Catarina, Brasil. \\ 2 Grupo de Estudos e Pesquisas Epidemiológicas em Atividade Física e Saúde da Universidade de \\ São Paulo, São Paulo, Brasil \\ 3 Escola de Artes, Ciências e Humanidades da \\ Universidade de São Paulo, São Paulo, Brasil. \\ 4 Universidade Tecnológica Federal do Paraná Programa de Pós-Graduação em Educação Física, Curitiba, Paraná, Brasil \\ 5 Grupo de Pesquisa em Ambiente, Atividade Física e Saúde da Universidade Tecnológica Federal do Paraná. Curitiba, Paraná, Brasil. \\ 6 Universidade Federal de Santa Maria, Núcleo de Estudos em Exercício Físico e Saúde, Centro de Educacão Física e Desportos, Santa Maria, Rio Grande do Sul, Brasil. \\ 7 Universidade Federal do Paraná, Centro de Estudos em Atividade Física e Saúde, Curitiba, Paraná, Brasil. \\ 8 Universidade Federal Rural de Pernambuco, Recife, Pernambuco, Brasil. \\ 9 Universidade Federal de Pernambuco, Programa de Pós-graduacão em Educação Física, Recife, Pernambuco, Brasil.}

\section{CORRESPONDING}

Paulo Henrique Guerra

paulo.guerra@ufs.edu.br

Rodovia SC 484, Km 02, Chapecó, Santa

Catarina, Brasil.

CEP: 89815-899.

DOI

$10.12820 /$ rbafs. $25 \mathrm{e} 0126$

\section{(cc) BY}

This work is licensed under a Creative Commons Attribution 4.0 International License.

\begin{abstract}
In order to identify the research that addressed the Academia da Cidade and Academia da Saúde Programs (ACP/ASP), a scoping review was conducted in April 2020 in five electronic databases and in reference lists aiming to identify scientific articles that had data collections carried out in the facilities of the ACP/ASP or, that somehow involved the populations of the localities where the programs were implemented. Of the 321 initial records, the descriptive synthesis consisted of 59 studies, which had as their most frequent characteristics: cross-sectional design, use of quantitative approaches in data collection and analysis, Nutrition as a central topic, and involvement of users (adults and the elderly). In conclusion, longitudinal studies involving all actors (managers, practitioners and users) and covering different health topics, besides promoting the approximation between academia and decision makers, may be promising in the sense of better evaluating the impact that the program represents in the life of the communities that are attended.
\end{abstract}

Keywords: Public policy; Health promotion; Adult; Aged; Review.

RESUMO

No sentido de identificar as pesquisas que abordam os Programas Academia da Cidade e Academia da Saúde (PAC/PAS), em abril de 2020 foi conduzida uma revisão de escopo, em cinco bases de dados eletrônicas em listas de referências, a fim de identificar artigos cientificos originais que tiveram coletas de dados realizadas nas instalaçôes do PAC/PAS ou, que, de alguma forma envolveram as populaçôes das localidades em que foram implantados os programas. De 321 registros iniciais, a sintese foi composta por 59 artigos cientificos, que apresentaram como características mais frequentes: delineamento transversal, uso de abordagens quantitativas nas coletas e análises de dados, Nutrição como temática central e envolvimento de usuários (adultos e idosos). Em conclusão, estudos longitudinais envolvendo todos os atores (gestores, profissionais e usuários) e distintas temáticas da saúde, além de promoverem a aproximação entre a academia e tomadores de decisão, podem ser promissores no sentido de melhor avaliar o impacto que o programa representa na vida das comunidades que são atendidas.

Palavras-chave: Política pública; Promoção da saúde; Adulto; Idoso; Revisão.

\section{Introduction}

In a broader perspective of health, which takes into account both interprofessional work and the social and structural determinants of people, in 2002 the Academia da Cidade Program (ACP) was introduced in Recife, Pernambuco (http://www2.recife.pe.gov.br/ 
servico/academia-da-cidade) as a public policy to expand the community access to educational actions, aimed to promoting body practices and physical activities (BPPA) $)^{1}$, which at the time emerged as priorities in the national public health agenda, much for the recognition of their preventive role in the face of non-communicable diseases ${ }^{2}$.

Over the years, in clear recognition of its success, the ACP has been redesigned and in 2011 expanded to the national level, being called Academia da Saúde Program (ASP) ${ }^{3}$. It is worth mentioning that the ASP was introduced after the publication of the national health promotion policy ${ }^{4}$ which organizes and guides the ways to promote health in the country under the principles of universality and equity ${ }^{5,6}$ and its operationalization, in summary, is through the implementation of public spaces (poles) with infrastructure and qualified practitioners, offering actions aimed at promoting healthy lifestyles and leisure ${ }^{3}$.

Given its potential, the ACP/ASP have become the focus of several research projects, and important aspects of its implementation have also come to be discussed in the academic area, in different themes ${ }^{7-10}$, which justifies the elaboration of a synthesis that may, in addition to presenting its state of the art, support the elaboration of future studies in its contexts. Thus, this study aimed to analyze the characteristics of the scientific articles that were developed in the contexts of these programs, identifying locations, themes, approaches and populations covered.

\section{Methods}

In order to identify and map the available evidence, this research is characterized as a Scoping Review ${ }^{11}$.

As inclusion criteria, original studies were searched, which had data collections performed at the ACP/ ASP facilities or, which somehow involved the populations of the localities where these programs were implemented, without restrictions in regard of the data collection and publication years, health topics covered, study designs, approaches used in data collection and analysis and populations, either in their relationship to the programs (e.g. managers, practitioners, users) or by any specific characteristics (e.g. age group, clinical condition and socioeconomic condition).

On April 9,2020, potential studies were retrieved by systematic searches in five electronic databases (Lilacs, Pubmed, Scielo, Scopus and Web of Science), based on the strategy applied in Pubmed: (( health gym[-
Text Word]) OR city gym[Text Word]) OR (((health gym[Text Word])) OR health academy[Text Word])) AND Brazil[Text Word]). To avoid the loss of relevant material, complementary searches were also made in the reference lists of studies evaluated by their full texts.

The duplicates were checked by one researcher (PG) and the titles and abstracts screening were made by two researchers (MT and PG), independently, with the participation of a third researcher (DA) to define eligibility. Subsequently, all researchers (CA, DS, DA, $\mathrm{EC}, \mathrm{MT}, \mathrm{PG}, \mathrm{RF}$ ) participated in the full text's assessment and the data extraction, also independently, having their work double checked.

The data extraction occurred in an electronic spreadsheet, organized from the program identification (e.g. if $\mathrm{ACP}$ or ASP), health topic(s) covered, place of research, year of data collection, sample size, age range, research design and approach(es) used for data collection and statistical analysis. After this stage the data were exported to the SPSS program, where the descriptive analyses (relative and absolute frequencies) were performed.

\section{Results}

At all, 318 articles were found by systematic searches (Figure 1). After exclusion of 100 duplicates among the databases, of the 221 articles screened by their titles and abstracts, 148 were classified as ineligible ( $\mathrm{n}$ = 109 by agreement between the two independent researchers; $n=39$ by decision of the third researcher). Thus, of the 70 articles evaluated by its full texts, 14 were excluded, considering the reasons: "non approach of the programs" ( $n=8)$ and "study design" $(n=6)$. Given the inclusion of three studies from manual searches, the descriptive synthesis of this review was based on data of 59 original studies, detailed in Appendix 1.

Table 1 shows that the largest portion of the studies related to ACP/ASP was published between 2015 and 2019 ( $n=41 ; 69.5 \%)$. By denomination, 32 articles were conducted in the context of the ACP (54.2\%) and, by location, studies conducted in Belo Horizonte $(\mathrm{n}=27 ; 45.8 \%)$ and in Recife $(\mathrm{n}=17 ; 28.7 \%)$ can be highlighted. Regarding the covered topics, Nutrition $(\mathrm{n}=22 ; 37.3 \%)$ and Assessment of Program ( $\mathrm{n}=19$; 32.2\%) prevailed. Most of the articles presented data collections between 2010 and 2014 ( $n=27 ; 45.8 \%)$.

Considering the participants relationship with the program, it was observed that "users" were the most represented category among the included studies, with 44 of them, either exclusively with users $(n=38)$ or evaluat- 


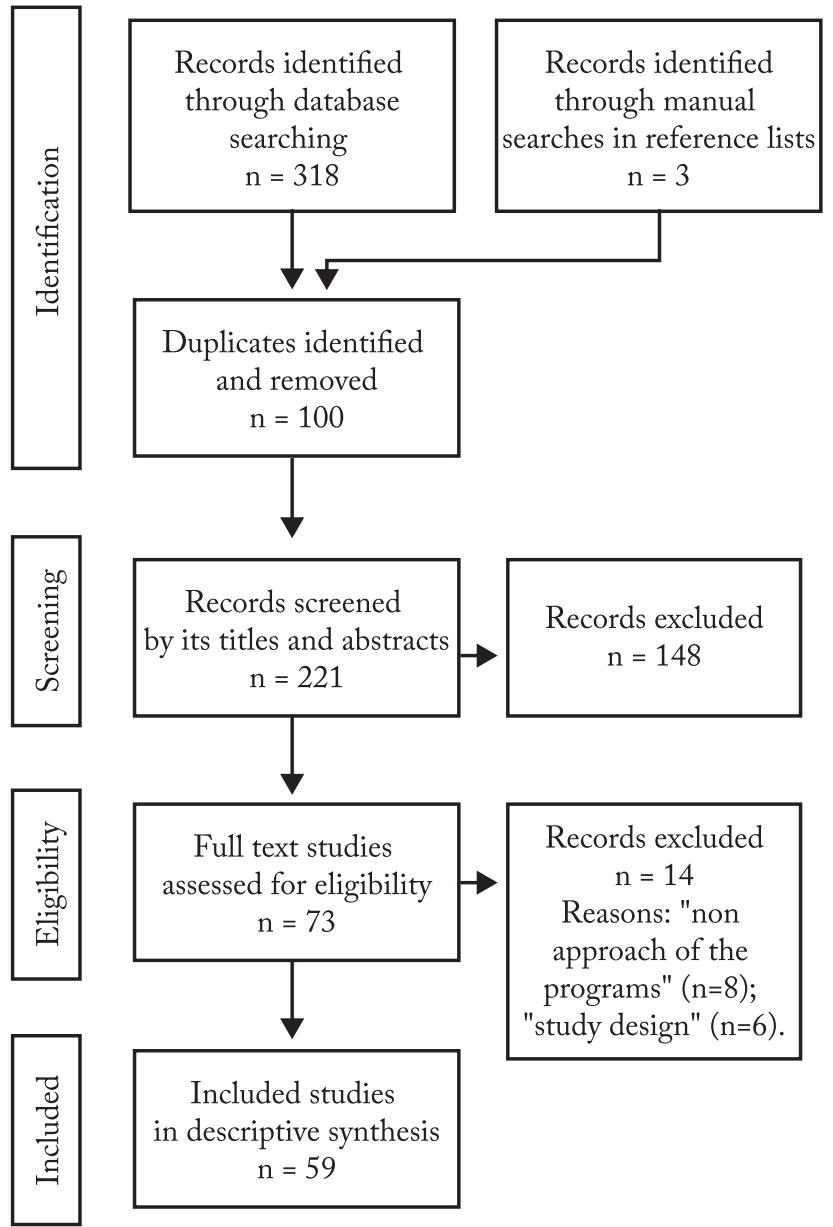

Figure 1 - Flowchart of systematic review.

ed with managers and practitioners $(n=4)$, practitioners $(n=1)$ or territories $(n=1)$. Considering the studies that involved users in the samples $(n=44)$, sample sizes varied among the studies, with more frequent samples between 100 and 499 participants $(\mathrm{n}=14 ; 31.8 \%)$ and equal to or above 1000 participants $(n=13 ; 29.5 \%)$. Most surveys addressed both sexes $(n=29 ; 65.9 \%)$ and involving populations of adults and older adults $(n=30 ; 68.2 \%)$ - Table 2. Table 2 also highlights the high frequency of studies that presented cross-sectional design ( $\mathrm{n}=41$; 69.5\%) and the predominance of quantitative approaches for data collection and analysis $(n=37 ; 62.7 \%)$.

\section{Discussion}

The beginning of the ACP in the Recife (2002) came about as a policy and the main guidelines proposed the construction of a Healthy Recife city, with metropolitan responsibility, integrated actions, decentralized planning and participatory budgeting to meet the health needs of the population, with an expanded focus on actions to health promotion and care. Thus, it can be
Table 1 - Descriptive characteristics of included studies developed on Academia da Cidade Program/Academia da Saúde Program ( $=59)$.

\begin{tabular}{|c|c|c|}
\hline Variables & $\mathrm{n}$ & $\%$ \\
\hline \multicolumn{3}{|l|}{ Year of publication } \\
\hline 2015-2019 & 41 & 69.5 \\
\hline 2010-2014 & 15 & 25.4 \\
\hline 2009 & 2 & 3.4 \\
\hline 2020 & 1 & 1.7 \\
\hline \multicolumn{3}{|l|}{ Denominations } \\
\hline Academia da Cidade Program & 32 & 54.2 \\
\hline Academia da Saúde Program & 27 & 45.8 \\
\hline \multicolumn{3}{|l|}{ Study location - City (State) } \\
\hline Belo Horizonte (Minas Gerais) & 27 & 45.8 \\
\hline Recife (Pernambuco) & 17 & 28.7 \\
\hline Aracaju (Sergipe) & 4 & 6.8 \\
\hline Country wide & 4 & 6.8 \\
\hline Rio de Janeiro (Rio de Janeiro) & 2 & 3.4 \\
\hline Pernambuco State & 1 & 1.7 \\
\hline Petrolina (Pernambuco) & 1 & 1.7 \\
\hline Santa Catarina State & 1 & 1.7 \\
\hline Two cities of São Paulo State & 1 & 1.7 \\
\hline Vitória (Espírito Santo) & 1 & 1.7 \\
\hline \multicolumn{3}{|l|}{ Topics covered by the studies } \\
\hline Nutrition & 22 & 37.3 \\
\hline Program Assessment & 19 & 32.2 \\
\hline Mixed & 7 & 11.9 \\
\hline Physical activity & 5 & 8.5 \\
\hline Quality of life & 3 & 5.1 \\
\hline Conception of health & 2 & 3.4 \\
\hline Women health & 1 & 1.7 \\
\hline \multicolumn{3}{|l|}{ Year of data collection } \\
\hline 2010-2014 & 27 & 45.8 \\
\hline 2005-2009 & 12 & 20.3 \\
\hline 2015-2017 & 10 & 16.9 \\
\hline Not described & 9 & 15.3 \\
\hline 2002-2004 & 1 & 1.7 \\
\hline
\end{tabular}

considered that the studies developed in their contexts were also important in their consolidation and expansion to the national level in $2011^{3}$, presenting the potential of this public policy, not only in the specificity of the promotion of BPPA, but also in other health topics, such as Nutrition, Quality of Life and Women's Health.

In this sense, Nutrition was the most frequent health topic covered among the included studies, with emphasis on the studies developed by researchers from Federal University of Minas Gerais. It's important to highlight that Brazil has a national dietary guideline ${ }^{12}$, which, in some way, may be supporting the interest and research in the theme. More specifically, these studies about Nutrition address important issues such as food 
Table 2 - Descriptive characteristics of included studies developed on Academia da Cidade Program/Academia da Saúde Program (n = 59).

\begin{tabular}{|c|c|c|}
\hline Variables & $\mathrm{n}$ & $\%$ \\
\hline \multicolumn{3}{|l|}{ Participants of study } \\
\hline Users & 38 & 64.4 \\
\hline Practitioners & 6 & 10.1 \\
\hline Managers & 5 & 8.5 \\
\hline Managers and practitioners & 4 & 6.8 \\
\hline Managers, practitioners and users & 4 & 6.8 \\
\hline Practitioners and users & 1 & 1.7 \\
\hline Users and territories & 1 & 1.7 \\
\hline \multicolumn{3}{|c|}{ Sample size (in studies conducted with users; $\mathrm{n}=44$ ) } \\
\hline $100-499$ & 14 & 31.8 \\
\hline$\geq 1000$ & 13 & 29.5 \\
\hline $1-49$ & 8 & 18.2 \\
\hline $50-99$ & 4 & 9.0 \\
\hline $500-999$ & 4 & 9.0 \\
\hline Not described & 2 & 4.5 \\
\hline \multicolumn{3}{|c|}{ Sex (in studies conducted with users; $n=44$ ) } \\
\hline Females and males & 29 & 65.9 \\
\hline Females & 13 & 29.6 \\
\hline Not described & 2 & 4.5 \\
\hline \multicolumn{3}{|c|}{ Age range (in studies conducted with users; $\mathrm{n}=44$ ) } \\
\hline Adults and older Adults & 30 & 68.2 \\
\hline Adults & 10 & 22.8 \\
\hline Older adults & 2 & 4.5 \\
\hline Not described & 2 & 4.5 \\
\hline \multicolumn{3}{|l|}{ Study design } \\
\hline Cross-sectional study & 41 & 69.5 \\
\hline Case study & 9 & 15.3 \\
\hline Intervention study & 7 & 11.8 \\
\hline Ecologic & 2 & 3.4 \\
\hline \multicolumn{3}{|l|}{ Data collection and analysis approach } \\
\hline Quantitative & 37 & 62.7 \\
\hline Qualitative & 18 & 30.5 \\
\hline Mixed & 4 & 6.8 \\
\hline
\end{tabular}

consumption, food profile, nutritional status, knowledge about healthy eating habits and food environment.

It is interesting to note that the ACP in Belo Horizonte began in 2006 (https://prefeitura.pbh.gov.br/saude/informacoes/atencao-a-saude/promocao-da-saude/ academia-da-cidade), four years later than the precursor program in Recife, and presented a larger academic production, possibly showing a greater interest of the university in local public policy, which we cannot say if the evidence produced was shared and used by public power. Bringing these actors together, from the beginning of the identification of problems to be investigated, may generate relevant public policy research ${ }^{13}$.

On the other hand, only five studies presented the
BPPA as their central topic. In view of the program proposal and the dynamics of the activities offered at the poles, surveys and intervention studies could be conducted in the context of the ACP/ASP, not only related to users and the profile of the activities developed. As a consequence of a two-way approach between public authorities and research institutions, intervention projects can be developed to provide continuing education to managers, practitioners and users, as well as longitudinal studies aimed at users, from a broader perspective both in terms of objectives (e.g., with the aim of identifying preferences, barriers and facilitators) and the use of mixed approaches to identifying phenomena (qualitative and quantitative). These are very important points since the introduction of the ACP/ASP aims to reduce inequity in access to the BPPA in the country.

None of the included studies were focused on samples of children and adolescents. This can be justified by the characteristics of the programs, such as opening hours and types of activities offered, which can be more attractive to adult and elderly populations, especially women. In Sá et al. ${ }^{14}$ it can be observed that managers point out as one of the main difficulties to cover activities with children and adolescents in the context of the ASP. Given the high indicators of physical inactivity ${ }^{15}$ and consumption of ultra-processed foods ${ }^{16}$, it is important that new strategies are developed for children and adolescents to be covered by the activities of PAS.

When analyzing the categories of quality evaluation, proposed by Donabedian $(1980)^{17}$ studies were divided into three categories: structure, process and outcome evaluation. We found that out of 59 studies, 36 (61\%) evaluated the outcome identified by physical activity or nutrition variables as analysis' outcomes and 23 (39\%) studies evaluated programs' structure or process.

One limitation that can be highlighted in the set of studies included is the lack of application of evaluation theories or models. Although different qualitative and quantitative methods have been used among the original studies, few offer a more comprehensive proposal of the analysis model, which goes beyond the analysis of effectiveness (e.g., verification of effects on specific outcomes - often biological). It is important that future studies introduce evaluation models, such as the REAIM mode ${ }^{18}$ that would enable an analysis of other important elements of the Program, such as: scope, effectiveness, maintenance, adoption, implementation.

The absence of searches for potential studies on dissertations and theses databases, as well as other 
types of publication, such as annals of congresses, may be considered a limitation of this study. The option of not including other scientific publications was because, usually, dissertations, theses and abstracts become full articles further up. On the other hand, it can be pointed out that, this being a scoping review, its synthesis allowed a look at the state of the art of studies conducted in the context of the ACP/ASP, stimulating the discussion of its potentials, limitations and advances.

Finally, data from this review suggest that most studies developed in the context of the ACP/ASP presented a transversal design, with quantitative approaches to data collection and analysis, had the Nutrition as its central topic and was directed to users (adults and the older adults). Longitudinal studies involving all actors (managers, practitioners and users), in addition to promoting rapprochement between universities and public policies, could be promising in the sense of better assessing the impact that the program represents in the life of the communities that are served by it. In this way, valuable information would be gained that would reinforce the ACP/ASP as a public policy of proven effectiveness and base-evidence recommended for large-scale implementation in the country.

\section{Conflict of interest}

The authors declare no conflict of interest.

\section{Author's contributions}

Guerra PH, conception of the central idea of the study, elaboration of systematic searches, screening of titles and abstracts, full texts assessment, descriptive synthesis development, analysis of results and writing of the text; Andrade DR, screening of titles and abstracts, full texts assessment, descriptive synthesis development, analysis of results and revision of the text; Rodriguez-Añez CR, full texts assessment, descriptive synthesis development, analysis of results and revision of the text; Santos DL, full texts assessment, descriptive synthesis development, analysis of results and revision of the text; Camargo EM, full texts assessment, descriptive synthesis development, analysis of results and revision of the text; Fermino RC, full texts assessment, descriptive synthesis development, analysis of results and revision of the text; Tenorio MCM, screening of titles and abstracts, full texts assessment, descriptive synthesis development, analysis of results and revision of the text.

\section{References}

1. Hallal PC, Carvalho YM, Tassitano, RM, Tenório MCM, Warschauer M, Reis RS, et al. Quali-quantitative evaluation of the "Academia da Cidade" Program from Recife, Brazil: perceptions of the professionals working in the program. Rev Bras Ativ Fis Saúde. 2009;14:9-14.
2. Loch MR, Knuth AG, Silva ICM, Guerra PH. Body practices/physical activity in the 30 years of the Unified Health System. Cienc Saúde Coletiva. 2018;23:3469.

3. Brasil. Ministério da Saúde. Portaria no 1.401, de 15 de junho de 2011. Institui, no âmbito da Política Nacional de Atenção Básica, o Incentivo para construção de Pólos da Academia da Saúde. Brasília: Ministério da Saúde; 2011. Disponível em: http://bvsms.saude.gov.br/bvs/saudelegis/gm/2011/ prt1402_15_06_2011.html.

4. Brasil. Ministério da Saúde. Secretaria de Vigilância em Saúde. Política Nacional de Promoção da Saúde. Portaria ${ }^{\circ}$ 687 MS/GM, de 30 de março de 2006. Aprova a Política de Promoção da Saúde. Brasília: Ministério da Saúde; 2006. Disponível em: http://bvsms.saude.gov.br/bvs/publicacoes/ politica_nacional_promocao_saude_3ed.pdf .

5. Brasil. Ministério da Saúde. Portaria no 154, de 24 de janeiro de 2008. Cria os Núcleos de Apoio à Saúde da Família NASF. Brasília: Ministério da Saúde; 2008. Disponível em: http://bvsms.saude.gov.br/bvs/saudelegis/gm/2008/ prt0154_24_01_2008.html.

6. Brasil. Ministério da Saúde. Secretaria de Vigilância em Saúde. Departamento de Análise de Situação de Saúde. Plano de ações estratégicas para o enfrentamento das doenças crônicas não transmissíveis (DCNT) no Brasil 2011-2022 / Ministério da Saúde. Secretaria de Vigilância em Saúde. Departamento de Análise de Situação de Saúde. - Brasília: Ministério da Saúde, 2011. 160 p.: il. - (Série B. Textos Básicos de Saúde).

7. Melo EHR, Guarda FRB, Feitosa WMN, Menezes VG. Classifying the types of evidence produced on the Academia da Cidade Program: a scoping review. Rev Bras Ativ Fis Saúde. 2019;24:e0076.

8. Hallal PC, Tenório MCM, Tassitano RM, Reis RS, Carvalho YM, Cruz DKA, et al. Evaluation of the Academia da Cidade program to promote physical activity in Recife, Pernambuco State, Brazil: perceptions of users and non-users. Cad. Saúde Pública. 2010,26:70-8.

9. Fernandes AP, Andrade ACS, Ramos CGC, Friche AAL, Dias MAS, Xavier CC. Leisure-time physical activity in the vicinity of Academias da Cidade Program in Belo Horizonte, Minas Gerais State, Brazil: the impact of a health promotion program on the community. Cad. Saúde Pública. 2015,31:Sup:S1-S13.

10. Florindo AA, Nakamura PM, Farias Júnior JC, Siqueira FV, Reis RS, Cruz DKA, et al. Promotion of physical activity, healthy eating and family health in municipalities with health gym. Rev Bras Educ Fís Esporte. 2016;30:913-24.

11. Maciel MG, Saraiva LAS, Silva MM, Vieira Junior PR. Performance evaluation of the Health Gym Program in Belo Horizonte: a case study. Movimento. 2019;25:e25026.

12. Barbosa Filho VC, Tricco AC. Scoping review: a relevant methodological approach for knowledge synthesis in Brazil's health literature. Bras Ativ Fís Saúde. 2019;24:e0082.

13. Brasil. Ministério da Saúde. Secretaria de Atenção à Saúde. Departamento de Atenção Básica. Guia alimentar para a população brasileira / Ministério da Saúde, Secretaria de Atenção à Saúde, Departamento de Atenção Básica. - 2. ed., 1. reimpr. - Brasília: Ministério da Saúde, 2014. 156 p.

14. Giles-Corti B, Sallis JF, Sugiyama T, Frank LD, Lowe M, Owen N. Translating active living research into policy and practice: One important pathway to chronic disease prevention. J Public Health Policy. 2015;36:231-43. 
15. Sá GBAR, Dornelles GC, Cruz KG, Amorim RCA, Andrade SSCA, Oliveira TP, et al. The Health Academy Program as a strategy to promote health and healthy lifestyles: the national implementation scenario. Ciên Saúde Coletiva. 2016;21:1849-59.

16. Condessa LA, Soares CA, Mielke GI, Malta DC, Caiaffa WT. Prevalence of physically active adolescents in Brazilian capitals: National Adolescent School-based Health Survey 2012 and 2015. Rev Bras Epidemiol. 2018;21(Suppl 1):E180012.supl.1.

17. Fonseca PCA, Ribeiro SAV, Andreoli CS, Carvalho CA, Pessoa MC, Novaes JF. Association of exclusive breastfeeding duration with consumption of ultra-processed foods, fruit and vegetables in Brazilian children. Eur J Nutr. 2019;58:2887-94.
18. Donabedian A. La calidad de La atención médica: definición y métodos de evaluación. Mexico: La Prensa Médica Mexicana, 1980.

19. Brito FA, Benedetti TRB, Tomicki C, Konrad LM, Sandreschi PF, Manta SW et al. Translation and adaptation of the RE-AIM Check List for Brazilian reality. Rev Bras Ativ Fís Saúde. 2018;23:e033.

\section{Quote this article as:}

Guerra PH, Andrade DR, Rodriguez-Añez CR, Santos DL, Camargo EM, Fermino RC, Tenório MCM. Research on the Academia da Cidade and Academia da Saúde Programs: scoping review. Rev Bras Ativ Fís Saúde. 2020;25:e0126. DOI: 10.12820/rbafs.25e0126

Appendix 1 - General description of included studies $(n=59)$

\begin{tabular}{|c|c|c|c|c|c|c|c|c|c|}
\hline Authors & Title & Topic & Study location & $\begin{array}{l}\text { Sample } \\
\text { size }\end{array}$ & Relationship & Sex $^{*}$ & $\begin{array}{l}\text { Age } \\
\text { range* }\end{array}$ & $\begin{array}{l}\text { Study } \\
\text { design }\end{array}$ & Approach \\
\hline \multicolumn{10}{|c|}{ Academia da Cidade Program $(\mathrm{N}=32)$} \\
\hline $\begin{array}{l}\text { Alves et al. } \\
2015\end{array}$ & $\begin{array}{l}\text { Climacteric: intensity of symptoms and } \\
\text { sexual performance }\end{array}$ & $\begin{array}{l}\text { Woman } \\
\text { Health }\end{array}$ & $\begin{array}{l}\text { Recife } \\
\text { (Pernambuco) }\end{array}$ & 260 & Users & $\mathrm{F}$ & $\mathrm{A} / \mathrm{OA}$ & $\mathrm{CS}$ & QNT \\
\hline $\begin{array}{l}\text { Brandão et } \\
\text { al. } 2012\end{array}$ & $\begin{array}{l}\text { Self-reported health and quality of life } \\
\text { among hikers attending the Academia das } \\
\text { Cidades Program, Petrolina, Pernambuco, } \\
\text { Brazil }\end{array}$ & $\begin{array}{l}\text { Quality of } \\
\text { Life }\end{array}$ & $\begin{array}{l}\text { Petrolina } \\
\text { (Pernambuco) }\end{array}$ & 300 & Users & $\mathrm{F} / \mathrm{M}$ & $\mathrm{A} / \mathrm{OA}$ & CS & QNT \\
\hline $\begin{array}{l}\text { Cazarin et } \\
\text { al., } 2019\end{array}$ & $\begin{array}{l}\text { Sustainability analysis of a health } \\
\text { promotion intervention in Recife, } \\
\text { Pernambuco, Brazil }\end{array}$ & $\begin{array}{l}\text { Program } \\
\text { Assessment }\end{array}$ & $\begin{array}{l}\text { Recife } \\
\text { (Pernambuco) }\end{array}$ & 39 & $\begin{array}{l}\text { Manag., } \\
\text { Pract. and } \\
\text { Users }\end{array}$ & nd & nd & Case & QLT \\
\hline $\begin{array}{l}\text { Costa et al., } \\
2012\end{array}$ & $\begin{array}{l}\text { Healthy eating index of women exercising } \\
\text { in the "City Gym Program", Aracajú, } \\
\text { Sergipe, Brazil }\end{array}$ & Nutrition & Aracaju (Sergipe) & 169 & Users & $\mathrm{F}$ & A & CS & QNT \\
\hline $\begin{array}{l}\text { Costa et al., } \\
2012\end{array}$ & $\begin{array}{l}\text { Profile of health, nutritional status and } \\
\text { knowledge of level in nutrition Academia } \\
\text { da Cidade Program of users - Aracaju, } \\
\text { Sergipe }\end{array}$ & Nutrition & Aracaju (Sergipe) & 191 & Users & $\mathrm{F}$ & A & CS & QNT \\
\hline $\begin{array}{l}\text { Costa et al., } \\
2013\end{array}$ & $\begin{array}{l}\text { City Academy: a health promotion service } \\
\text { in the healthcare network of the Unified } \\
\text { Health System }\end{array}$ & Nutrition & $\begin{array}{l}\text { Belo Horizonte } \\
\text { (Minas Gerais) }\end{array}$ & 560 & Users & $\mathrm{F}$ & $\mathrm{A} / \mathrm{OA}$ & $\mathrm{CS}$ & QNT \\
\hline $\begin{array}{l}\text { Feitosa et al., } \\
2016\end{array}$ & $\begin{array}{l}\text { Users'perception of actions, improvement } \\
\text { in quality of life and satisfaction with the } \\
\text { Academia da Cidade Program }\end{array}$ & Mixed & $\begin{array}{l}\text { Recife } \\
\text { (Pernambuco) }\end{array}$ & 28 & Users & $\mathrm{F}$ & $\mathrm{A} / \mathrm{OA}$ & Case & QLT \\
\hline $\begin{array}{l}\text { Fernandes et } \\
\text { al., } 2015\end{array}$ & $\begin{array}{l}\text { Leisure-time physical activity in the } \\
\text { vicinity of Academias da Cidade Program } \\
\text { in Belo Horizonte, Minas Gerais State, } \\
\text { Brazil: the impact of a health promotion } \\
\text { program on the community }\end{array}$ & $\begin{array}{l}\text { Physical } \\
\text { Activity }\end{array}$ & $\begin{array}{l}\text { Belo Horizonte } \\
\text { (Minas Gerais) }\end{array}$ & 1,621 & Users & $\mathrm{F} / \mathrm{M}$ & $\mathrm{A} / \mathrm{OA}$ & IS & QLT \\
\hline $\begin{array}{l}\text { Fonte et al., } \\
2016\end{array}$ & $\begin{array}{l}\text { Effects of a physical activity program on } \\
\text { the quality of life among elderly people } \\
\text { in Brazil }\end{array}$ & $\begin{array}{l}\text { Quality of } \\
\text { Life }\end{array}$ & $\begin{array}{l}\text { Recife } \\
\text { (Pernambuco) }\end{array}$ & 181 & Users & $\mathrm{F} / \mathrm{M}$ & $\mathrm{OA}$ & $\mathrm{CS}$ & QLT \\
\hline $\begin{array}{l}\text { Hallal et al., } \\
2009\end{array}$ & $\begin{array}{l}\text { Quali-quantitative evaluation of } \\
\text { the "Academia da Cidade" program } \\
\text { from recife, brazil: perceptions of the } \\
\text { professionals working in the program }\end{array}$ & $\begin{array}{l}\text { Program } \\
\text { Assessment }\end{array}$ & $\begin{array}{l}\text { Recife } \\
\text { (Pernambuco) }\end{array}$ & 12 & Pract. & na & na & CS & Mixed \\
\hline
\end{tabular}

Continue... 
... continue

\begin{tabular}{|c|c|c|c|c|c|c|c|c|c|}
\hline Authors & Title & Topic & Study location & $\begin{array}{l}\text { Sample } \\
\text { size }\end{array}$ & Relationship & Sex ${ }^{*}$ & $\begin{array}{l}\text { Age } \\
\text { range* }\end{array}$ & $\begin{array}{l}\text { Study } \\
\text { design }\end{array}$ & Approach \\
\hline $\begin{array}{l}\text { Hallal et al., } \\
2010\end{array}$ & $\begin{array}{l}\text { Evaluation of the Academia da Cidade } \\
\text { program to promote physical activity } \\
\text { in Recife, Pernambuco State, Brazil: } \\
\text { perceptions of users and non-users }\end{array}$ & $\begin{array}{l}\text { Program } \\
\text { Assessment }\end{array}$ & $\begin{array}{l}\text { Recife } \\
\text { (Pernambuco) }\end{array}$ & 554 & Users & $\mathrm{F} / \mathrm{M}$ & $\mathrm{A} / \mathrm{OA}$ & $\mathrm{CS}$ & QNT \\
\hline $\begin{array}{l}\text { Horta; } \\
\text { Santos, } 2015\end{array}$ & $\begin{array}{l}\text { Dietary quality among overweight women } \\
\text { attended in an 'Academia da Cidade' in } \\
\text { Belo Horizonte, Minas Gerais state }\end{array}$ & Nutrition & $\begin{array}{l}\text { Belo Horizonte } \\
\text { (Minas Gerais) }\end{array}$ & 140 & Users & $\mathrm{F}$ & $\mathrm{A} / \mathrm{OA}$ & CS & QNT \\
\hline $\begin{array}{l}\text { Lemos et al., } \\
2016\end{array}$ & $\begin{array}{l}\text { City Academy program: description of } \\
\text { adhesion factors and nonadherence }\end{array}$ & $\begin{array}{l}\text { Program } \\
\text { Assessment }\end{array}$ & $\begin{array}{l}\text { Recife } \\
\text { (Pernambuco) }\end{array}$ & 822 & Users & $\mathrm{F} / \mathrm{M}$ & A & $\mathrm{CS}$ & QNT \\
\hline $\begin{array}{l}\text { Lemos et al., } \\
2016\end{array}$ & $\begin{array}{l}\text { Factors associated with adherence to the } \\
\text { Academia da Cidade Program in Recife }\end{array}$ & $\begin{array}{l}\text { Program } \\
\text { Assessment }\end{array}$ & $\begin{array}{l}\text { Recife } \\
\text { (Pernambuco) }\end{array}$ & 533 & Users & $\mathrm{F} / \mathrm{M}$ & A & $\mathrm{CS}$ & QNT \\
\hline $\begin{array}{l}\text { Lopes et al., } \\
2012\end{array}$ & $\begin{array}{l}\text { Factors associated to overweight among } \\
\text { women }\end{array}$ & Nutrition & $\begin{array}{l}\text { Belo Horizonte } \\
\text { (Minas Gerais) }\end{array}$ & 262 & Users & $\mathrm{F}$ & $\mathrm{A} / \mathrm{OA}$ & CS & QNT \\
\hline $\begin{array}{l}\text { Maciel et al., } \\
2018\end{array}$ & $\begin{array}{l}\text { Analysis of the discourse on health in a } \\
\text { governmental program of physical activity }\end{array}$ & $\begin{array}{l}\text { Conception } \\
\text { of Health }\end{array}$ & $\begin{array}{l}\text { Belo Horizonte } \\
\text { (Minas Gerais) }\end{array}$ & 18 & $\begin{array}{l}\text { Manag., } \\
\text { Pract. and } \\
\text { Users }\end{array}$ & $\mathrm{F} / \mathrm{M}$ & A & Case & QLT \\
\hline $\begin{array}{l}\text { Maciel et al., } \\
2019\end{array}$ & $\begin{array}{l}\text { Discursive analysis about health } \\
\text { promotion in a governmental program of } \\
\text { physical activity }\end{array}$ & $\begin{array}{l}\text { Conception } \\
\text { of Health }\end{array}$ & $\begin{array}{l}\text { Belo Horizonte } \\
\text { (Minas Gerais) }\end{array}$ & 18 & $\begin{array}{l}\text { Manag., } \\
\text { Pract. and } \\
\text { Users }\end{array}$ & $\mathrm{F} / \mathrm{M}$ & A & Case & QLT \\
\hline $\begin{array}{l}\text { Melo et al., } \\
2016\end{array}$ & $\begin{array}{l}\text { Performance of Physical Education } \\
\text { Professionals from the Academia da } \\
\text { Cidade Program in Primary Health Care } \\
\text { in Recife }\end{array}$ & $\begin{array}{l}\text { Program } \\
\text { Assessment }\end{array}$ & $\begin{array}{l}\text { Recife } \\
\text { (Pernambuco) }\end{array}$ & 104 & Pract. & $\mathrm{F} / \mathrm{M}$ & $\mathrm{A} / \mathrm{OA}$ & $\mathrm{CS}$ & QNT \\
\hline $\begin{array}{l}\text { Mendonça et } \\
\text { al., } 2010\end{array}$ & $\begin{array}{l}\text { Exposure to a community-wide physical } \\
\text { activity promotion program and leisure- } \\
\text { time physical activity in Aracaju, Brazil }\end{array}$ & Mixed & Aracaju (Sergipe) & 2,267 & Users & $\mathrm{F} / \mathrm{M}$ & $\mathrm{A} / \mathrm{OA}$ & $\mathrm{CS}$ & QNT \\
\hline $\begin{array}{l}\text { Menezes et } \\
\text { al., } 2011\end{array}$ & $\begin{array}{l}\text { Factors Associated with Diabetes Mellitus } \\
\text { in Participants of the 'Academia da } \\
\text { Cidade' Program in the Eastern Region of } \\
\text { the Municipality of Belo Horizonte, State } \\
\text { of Minas Gerais, Brazil, } 2007 \text { and } 2008\end{array}$ & Nutrition & $\begin{array}{l}\text { Belo Horizonte } \\
\text { (Minas Gerais) }\end{array}$ & 364 & Users & $\mathrm{F} / \mathrm{M}$ & $\mathrm{A} / \mathrm{OA}$ & $\mathrm{CS}$ & QNT \\
\hline $\begin{array}{l}\text { Moreira et } \\
\text { al., } 2014\end{array}$ & $\begin{array}{l}\text { Eating behavior toward oil and fat } \\
\text { consumption versus dietary fat intake }\end{array}$ & Nutrition & $\begin{array}{l}\text { Belo Horizonte } \\
\text { (Minas Gerais) }\end{array}$ & 168 & Users & $\mathrm{F}$ & $\mathrm{A}$ & $\mathrm{CS}$ & QNT \\
\hline $\begin{array}{l}\text { Moura et al., } \\
2016\end{array}$ & $\begin{array}{l}\text { Knowledge of Family Health Strategy } \\
\text { professionals regarding the Academia } \\
\text { da Cidade Program (ACP) in the city of } \\
\text { Recife }\end{array}$ & $\begin{array}{l}\text { Program } \\
\text { Assessment }\end{array}$ & $\begin{array}{l}\text { Recife } \\
\text { (Pernambuco) }\end{array}$ & 206 & Pract. & na & na & CS & QNT \\
\hline $\begin{array}{l}\text { Padilha et al., } \\
2015\end{array}$ & $\begin{array}{l}\text { Evaluability study of the Carioca Health } \\
\text { Academy Program: challenges for health } \\
\text { promotion }\end{array}$ & $\begin{array}{l}\text { Program } \\
\text { Assessment }\end{array}$ & $\begin{array}{l}\text { Rio de Janeiro (Rio } \\
\text { de Janeiro) }\end{array}$ & nd & Users & na & na & Case & QLT \\
\hline $\begin{array}{l}\text { Paes et al., } \\
2011\end{array}$ & $\begin{array}{l}\text { Lifestyle in hypertensive subjects } \\
\text { attending the "Academia da Cidade" } \\
\text { program, Recife, Brazil }\end{array}$ & Mixed & $\begin{array}{l}\text { Recife } \\
\text { (Pernambuco) }\end{array}$ & 78 & Users & $\mathrm{F} / \mathrm{M}$ & A & $\mathrm{CS}$ & QNT \\
\hline $\begin{array}{l}\text { Paez et al., } \\
2015\end{array}$ & $\begin{array}{l}\text { Bridging the gap between research and } \\
\text { practice: an assessment of external validity } \\
\text { of community-based physical activity } \\
\text { programs in Bogotá, Colombia, and } \\
\text { Recife, Brazil }\end{array}$ & $\begin{array}{l}\text { Physical } \\
\text { Activity }\end{array}$ & $\begin{array}{l}\text { Recife } \\
\text { (Pernambuco) }\end{array}$ & 17 & $\begin{array}{l}\text { Manag. and } \\
\text { Pract. }\end{array}$ & na & na & CS & QLT \\
\hline $\begin{array}{l}\text { Pajeu et al., } \\
2016\end{array}$ & $\begin{array}{l}\text { Interaction between the Family Health } \\
\text { Units and the Academia da Cidade } \\
\text { Program in Recife, Northeastern Brazil }\end{array}$ & $\begin{array}{l}\text { Program } \\
\text { Assessment }\end{array}$ & $\begin{array}{l}\text { Recife } \\
\text { (Pernambuco) }\end{array}$ & 203 & Pract. & na & na & $\mathrm{CS}$ & QNT \\
\hline $\begin{array}{l}\text { Pereira et al., } \\
2014\end{array}$ & $\begin{array}{l}\text { Women's meal frequency and nutritional } \\
\text { and health profiles }\end{array}$ & Nutrition & $\begin{array}{l}\text { Belo Horizonte } \\
\text { (Minas Gerais) }\end{array}$ & 342 & Users & $\mathrm{F}$ & $\mathrm{A} / \mathrm{OA}$ & CS & QNT \\
\hline
\end{tabular}

Continue... 


\begin{tabular}{|c|c|c|c|c|c|c|c|c|c|}
\hline Authors & Title & Topic & Study location & $\begin{array}{l}\text { Sample } \\
\text { size }\end{array}$ & Relationship & Sex* & $\begin{array}{l}\text { Age } \\
\text { range* }\end{array}$ & $\begin{array}{l}\text { Study } \\
\text { design }\end{array}$ & Approach \\
\hline $\begin{array}{l}\text { Silva et al., } \\
2013\end{array}$ & $\begin{array}{l}\text { Nutritional intervention workshops in a } \\
\text { health-promotion service of Belo } \\
\text { Horizonte, Minas Gerais }\end{array}$ & Nutrition & $\begin{array}{l}\text { Belo Horizonte } \\
\text { (Minas Gerais) }\end{array}$ & 132 & Users & $\mathrm{F} / \mathrm{M}$ & $\mathrm{A} / \mathrm{OA}$ & IS & QNT \\
\hline $\begin{array}{l}\text { Silva et al., } \\
2014\end{array}$ & $\begin{array}{l}\text { Access and use of the Community Fitness } \\
\text { Center of Belo Horizonte: the perspective } \\
\text { of users and monitors }\end{array}$ & $\begin{array}{l}\text { Program } \\
\text { Assessment }\end{array}$ & $\begin{array}{l}\text { Belo Horizonte } \\
\text { (Minas Gerais) }\end{array}$ & 25 & $\begin{array}{l}\text { Manag. and } \\
\text { Pract. }\end{array}$ & $\mathrm{F} / \mathrm{M}$ & $\mathrm{A} / \mathrm{OA}$ & Case & QLT \\
\hline $\begin{array}{l}\text { Simões et al., } \\
2009\end{array}$ & $\begin{array}{l}\text { Effects of a Community-Based, } \\
\text { Professionally Supervised Intervention on } \\
\text { Physical Activity Levels Among Residents } \\
\text { of Recife, Brazil }\end{array}$ & $\begin{array}{l}\text { Physical } \\
\text { Activity }\end{array}$ & $\begin{array}{l}\text { Recife } \\
\text { (Pernambuco) }\end{array}$ & 2,038 & Users & $\mathrm{F} / \mathrm{M}$ & $\mathrm{A} / \mathrm{OA}$ & $\mathrm{CS}$ & QNT \\
\hline $\begin{array}{l}\text { Simões et al., } \\
2017\end{array}$ & $\begin{array}{l}\text { Effectiveness of a scaled up physical } \\
\text { activity intervention in Brazil: A natural } \\
\text { experiment }\end{array}$ & $\begin{array}{l}\text { Physical } \\
\text { Activity }\end{array}$ & Pernambuco & 3,685 & Users & $\mathrm{F} / \mathrm{M}$ & $\mathrm{A} / \mathrm{OA}$ & IS & QNT \\
\hline $\begin{array}{l}\text { Teixeira et } \\
\text { al., } 2013\end{array}$ & $\begin{array}{l}\text { Educational nutritional intervention } \\
\text { as an effective tool for changing eating } \\
\text { habits and body weight among those who } \\
\text { practice physical activities }\end{array}$ & Mixed & Aracaju (SE) & 52 & Users & $\mathrm{F}$ & A & IS & QNT \\
\hline \multicolumn{10}{|c|}{ Academia da Saúde Program $(\mathrm{N}=27)$} \\
\hline $\begin{array}{l}\text { Carvalho et } \\
\text { al. } 2018\end{array}$ & $\begin{array}{l}\text { Perception versus intake of fruit and } \\
\text { vegetables }\end{array}$ & Nutrition & $\begin{array}{l}\text { Belo Horizonte } \\
\text { (Minas Gerais) }\end{array}$ & 3,414 & Users & $\mathrm{F} / \mathrm{M}$ & $\mathrm{A} / \mathrm{OA}$ & $\mathrm{CS}$ & QNT \\
\hline $\begin{array}{l}\text { Costa et al., } \\
2019\end{array}$ & $\begin{array}{l}\text { Does access to healthy food vary according } \\
\text { to socioeconomic status and to food store } \\
\text { type? an ecologic study }\end{array}$ & Nutrition & $\begin{array}{l}\text { Belo Horizonte } \\
\text { (Minas Gerais) }\end{array}$ & 2,831 & $\begin{array}{l}\text { Users and } \\
\text { Territories }\end{array}$ & $\mathrm{F}$ & $\mathrm{A} / \mathrm{OA}$ & Eco & QNT \\
\hline $\begin{array}{l}\text { Deus et al., } \\
2015\end{array}$ & $\begin{array}{l}\text { The impact of a nutritional intervention } \\
\text { on the nutritional status and } \\
\text { anthropometric profile of participants in } \\
\text { the Health Gym Programme in Brazil }\end{array}$ & Nutrition & $\begin{array}{l}\text { Belo Horizonte } \\
\text { (Minas Gerais) }\end{array}$ & 124 & Users & $\mathrm{F}$ & $\mathrm{A} / \mathrm{OA}$ & IS & QNT \\
\hline $\begin{array}{l}\text { Fernandes et } \\
\text { al., } 2017\end{array}$ & $\begin{array}{l}\text { Health Academies Program and the } \\
\text { promotion of physical activity in the city: } \\
\text { the experience of Belo Horizonte, Minas } \\
\text { Gerais, Brazil }\end{array}$ & $\begin{array}{l}\text { Physical } \\
\text { Activity }\end{array}$ & $\begin{array}{l}\text { Belo Horizonte } \\
\text { (Minas Gerais) }\end{array}$ & 4,450 & Users & $\mathrm{F} / \mathrm{M}$ & $\mathrm{A} / \mathrm{OA}$ & $\mathrm{CS}$ & Mixed \\
\hline $\begin{array}{l}\text { Ferreira et } \\
\text { al., } 2017\end{array}$ & $\begin{array}{l}\text { Social representations of older adults } \\
\text { regarding quality of life }\end{array}$ & $\begin{array}{l}\text { Qualidade } \\
\text { de Vida }\end{array}$ & $\begin{array}{l}\text { Rio de Janeiro (Rio } \\
\text { de Janeiro) }\end{array}$ & 30 & Users & $\mathrm{F} / \mathrm{M}$ & $\mathrm{OA}$ & $\mathrm{CS}$ & QLT \\
\hline $\begin{array}{l}\text { Figueira et } \\
\text { al., } 2014\end{array}$ & $\begin{array}{l}\text { Assessing fruit and vegetable consumption } \\
\text { among families of users of the Programa } \\
\text { Academia da Saúde (PAS) }\end{array}$ & Nutrition & $\begin{array}{l}\text { Belo Horizonte } \\
\text { (Minas Gerais) }\end{array}$ & 4 & Users & $\mathrm{F}$ & $\mathrm{A} / \mathrm{OA}$ & $\mathrm{CS}$ & QLT \\
\hline $\begin{array}{l}\text { Figueira et } \\
\text { al., } 2016\end{array}$ & $\begin{array}{l}\text { Promoters and barriers to fruit and } \\
\text { vegetable consumption among Health } \\
\text { Academy Program's users }\end{array}$ & Nutrition & $\begin{array}{l}\text { Belo Horizonte } \\
\text { (Minas Gerais) }\end{array}$ & 62 & Users & $\mathrm{F} / \mathrm{M}$ & $\mathrm{A} / \mathrm{OA}$ & $\mathrm{CS}$ & QLT \\
\hline $\begin{array}{l}\text { Florindo et } \\
\text { al., } 2016\end{array}$ & $\begin{array}{l}\text { Description of health promotion actions } \\
\text { in Brazilian cities that received funds to } \\
\text { develop "Academia da Saúde" }\end{array}$ & $\begin{array}{l}\text { Program } \\
\text { Assessment }\end{array}$ & National & 914 & Manag. & na & na & $\mathrm{CS}$ & QNT \\
\hline $\begin{array}{l}\text { Florindo et } \\
\text { al., } 2016\end{array}$ & $\begin{array}{l}\text { Promotion of physical activity, healthy } \\
\text { eating and family health in municipalities } \\
\text { with health gym }\end{array}$ & Mixed & National & 914 & Manag. & na & na & CS & QNT \\
\hline $\begin{array}{l}\text { Freitas et al., } \\
2019\end{array}$ & $\begin{array}{l}\text { Consumer food environment and } \\
\text { overweight }\end{array}$ & Nutrition & $\begin{array}{l}\text { Belo Horizonte } \\
\text { (Minas Gerais) }\end{array}$ & 2,810 & Users & $\mathrm{F} / \mathrm{M}$ & $\mathrm{A} / \mathrm{OA}$ & $\mathrm{CS}$ & Mixed \\
\hline $\begin{array}{l}\text { Guarda et } \\
\text { al., } 2015\end{array}$ & $\begin{array}{l}\text { Characterization of physical activity } \\
\text { program teams and their work process }\end{array}$ & $\begin{array}{l}\text { Program } \\
\text { Assessment }\end{array}$ & $\begin{array}{l}\text { Recife } \\
\text { (Pernambuco) }\end{array}$ & 18 & Pract. & na & na & $\mathrm{CS}$ & QLT \\
\hline $\begin{array}{l}\text { Guarda et } \\
\text { al., } 2016\end{array}$ & $\begin{array}{l}\text { Self-perception of the objective, object } \\
\text { and work products of Physical Education } \\
\text { Professionals belonging to the Academia } \\
\text { da Saúde Program }\end{array}$ & $\begin{array}{l}\text { Program } \\
\text { Assessment }\end{array}$ & $\begin{array}{l}\text { Recife } \\
\text { (Pernambuco) }\end{array}$ & 18 & Pract. & na & na & $\mathrm{CS}$ & QLT \\
\hline
\end{tabular}

Continue... 
... continue

\begin{tabular}{|c|c|c|c|c|c|c|c|c|c|}
\hline Authors & Title & Topic & Study location & $\begin{array}{l}\text { Sample } \\
\text { size }\end{array}$ & Relationship & Sex* & $\begin{array}{l}\text { Age } \\
\text { range* }\end{array}$ & $\begin{array}{l}\text { Study } \\
\text { design }\end{array}$ & Approach \\
\hline $\begin{array}{l}\text { Ivo, Malta e } \\
\text { Freitas, } 2019\end{array}$ & $\begin{array}{l}\text { Modes of thinking of the professionals } \\
\text { of the Health Academy Program about } \\
\text { health and disease and their implications } \\
\text { in actions of health promotion }\end{array}$ & $\begin{array}{l}\text { Program } \\
\text { Assessment }\end{array}$ & $\begin{array}{l}\text { Belo Horizonte } \\
\text { (Minas Gerais) }\end{array}$ & 32 & $\begin{array}{l}\text { Manag. and } \\
\text { Pract. }\end{array}$ & na & na & $\mathrm{CS}$ & QLT \\
\hline $\begin{array}{l}\text { Jorge et al., } \\
2018\end{array}$ & $\begin{array}{l}\text { Health Academy Program: association of } \\
\text { nutritional knowledge and anthropometric } \\
\text { parameters }\end{array}$ & Nutrition & $\begin{array}{l}\text { Vitória (Espírito } \\
\text { Santo) }\end{array}$ & 92 & Users & $\mathrm{F} / \mathrm{M}$ & $\mathrm{A} / \mathrm{OA}$ & CS & QNT \\
\hline $\begin{array}{l}\text { Machado et } \\
\text { al., } 2017\end{array}$ & $\begin{array}{l}\text { Misreporting of energy intake among } \\
\text { users of Health Promotion Services }\end{array}$ & Nutrition & $\begin{array}{l}\text { Belo Horizonte } \\
\text { (Minas Gerais) }\end{array}$ & 487 & Users & $\mathrm{F} / \mathrm{M}$ & $\mathrm{A} / \mathrm{OA}$ & $\mathrm{CS}$ & QNT \\
\hline $\begin{array}{l}\text { Maciel et al., } \\
2019\end{array}$ & $\begin{array}{l}\text { Performance evaluation of the Health } \\
\text { Gym Program in Belo Horizonte: a case } \\
\text { study }\end{array}$ & $\begin{array}{l}\text { Program } \\
\text { Assessment }\end{array}$ & $\begin{array}{l}\text { Belo Horizonte } \\
\text { (Minas Gerais) }\end{array}$ & 25 & $\begin{array}{l}\text { Manag., } \\
\text { Pract. and } \\
\text { Users }\end{array}$ & $\mathrm{F} / \mathrm{M}$ & A & Case & QLT \\
\hline $\begin{array}{l}\text { Mendonça et } \\
\text { al., } 2019\end{array}$ & $\begin{array}{l}\text { Monotony in the consumption of fruits } \\
\text { and vegetables and food environment } \\
\text { characteristics }\end{array}$ & Nutrition & $\begin{array}{l}\text { Belo Horizonte } \\
\text { (Minas Gerais) }\end{array}$ & 3,414 & Users & $\mathrm{F} / \mathrm{M}$ & $\mathrm{A} / \mathrm{OA}$ & $\mathrm{CS}$ & QNT \\
\hline $\begin{array}{l}\text { Mendonça et } \\
\text { al., } 2019\end{array}$ & $\begin{array}{l}\text { Barriers to and facilitators for adherence } \\
\text { to nutricional intervention: consumption } \\
\text { of fruits and vegetables }\end{array}$ & Nutrition & $\begin{array}{l}\text { Belo Horizonte } \\
\text { (Minas Gerais) }\end{array}$ & 1,483 & Users & $\mathrm{F} / \mathrm{M}$ & $\mathrm{A} / \mathrm{OA}$ & IS & Mixed \\
\hline $\begin{array}{l}\text { Menezes et } \\
\text { al., } 2017\end{array}$ & $\begin{array}{l}\text { Local food environment and fruit and } \\
\text { vegetable consumption: an ecological } \\
\text { study }\end{array}$ & Nutrition & $\begin{array}{l}\text { Belo Horizonte } \\
\text { (Minas Gerais) }\end{array}$ & 3,414 & Users & $\mathrm{F} / \mathrm{M}$ & $\mathrm{A} / \mathrm{OA}$ & Eco & QNT \\
\hline $\begin{array}{l}\text { Menezes et } \\
\text { al., } 2018\end{array}$ & $\begin{array}{l}\text { Fruit and vegetable intake: influence of } \\
\text { perceived food environment and self- } \\
\text { efficacy }\end{array}$ & Nutrition & $\begin{array}{l}\text { Belo Horizonte } \\
\text { (Minas Gerais) }\end{array}$ & 3,414 & Users & $\mathrm{F} / \mathrm{M}$ & $\mathrm{A} / \mathrm{OA}$ & $\mathrm{CS}$ & QNT \\
\hline $\begin{array}{l}\text { Menezes et } \\
\text { al., } 2018\end{array}$ & $\begin{array}{l}\text { Individual and food environmental factors: } \\
\text { association with diet }\end{array}$ & Nutrition & $\begin{array}{l}\text { Belo Horizonte } \\
\text { (Minas Gerais) }\end{array}$ & 2,944 & Users & $\mathrm{F} / \mathrm{M}$ & $\mathrm{A} / \mathrm{OA}$ & $\mathrm{CS}$ & QNT \\
\hline $\begin{array}{l}\text { Meurer et al., } \\
2019\end{array}$ & $\begin{array}{l}\text { Effectiveness of the VAMOS strategy for } \\
\text { increasing physical activity and healthy } \\
\text { dietary habits: a randomized controlled } \\
\text { community trial }\end{array}$ & Mixed & $\begin{array}{l}\text { Belo Horizonte } \\
\text { (Minas Gerais) }\end{array}$ & 291 & Users & $\mathrm{F} / \mathrm{M}$ & $\mathrm{A} / \mathrm{OA}$ & IS & QNT \\
\hline $\begin{array}{l}\text { Mota et al., } \\
2016\end{array}$ & $\begin{array}{l}\text { Federative relations at the Programa } \\
\text { Academia da Saúde (Health Academy } \\
\text { Program): study of two cities of the state } \\
\text { of São Paulo }\end{array}$ & $\begin{array}{l}\text { Program } \\
\text { Assessment }\end{array}$ & $\begin{array}{l}\text { Two cities of São } \\
\text { Paulo state }\end{array}$ & 5 & Manag. & na & na & Case & QLT \\
\hline $\begin{array}{l}\text { Paiva Neto } \\
\text { et al., } 2019\end{array}$ & $\begin{array}{l}\text { Barriers to implementation of "Academia } \\
\text { da saúde program" in Santa Catarina }\end{array}$ & $\begin{array}{l}\text { Program } \\
\text { Assessment }\end{array}$ & Santa Catarina state & 26 & Manag. & na & na & CS & QNT \\
\hline $\begin{array}{l}\text { Sá et al., } \\
2016\end{array}$ & $\begin{array}{l}\text { The Health Academy Program as a } \\
\text { strategy to promote health and healthy } \\
\text { lifestyles: the national implementation } \\
\text { scenario }\end{array}$ & $\begin{array}{l}\text { Program } \\
\text { Assessment }\end{array}$ & National & nd & Manag. & na & na & $\mathrm{CS}$ & QNT \\
\hline $\begin{array}{l}\text { Silva et al., } \\
2017\end{array}$ & $\begin{array}{l}\text { Evaluability of the Health Gym Program } \\
\text { in Recife, Pernambuco State, Brazil }\end{array}$ & $\begin{array}{l}\text { Program } \\
\text { Assessment }\end{array}$ & $\begin{array}{l}\text { Recife } \\
\text { (Pernambuco) }\end{array}$ & 14 & $\begin{array}{l}\text { Manag. and } \\
\text { Pract. }\end{array}$ & na & na & Case & QLT \\
\hline $\begin{array}{l}\text { Wolker et al., } \\
2020\end{array}$ & $\begin{array}{l}\text { Monitoring the Health Academy program } \\
\text { from } 2015 \text { to } 2017\end{array}$ & $\begin{array}{l}\text { Program } \\
\text { Assessment }\end{array}$ & National & na & $\begin{array}{l}\text { Manag. and } \\
\text { Pract. }\end{array}$ & na & na & $\mathrm{CS}$ & QNT \\
\hline
\end{tabular}

Legends: * information about users; $\mathrm{A}$ = adults; Case = case study; $\mathrm{CS}=$ cross-sectional; $\mathrm{F}=$ females; $\mathrm{IS}=$ intervention study; $\mathrm{M}=$ males; Manag = managers; na = not applicable; nd: not described $; \mathrm{AO}=$ : older adults; Pract = practitioners; $\mathrm{QLT}=$ qualitative; $\mathrm{QNT}=$ quantitative. 